\title{
PURSUING FUTURE FOREIGN LANGUAGE TEACHERS' PROFESSIONAL DEVELOPMENT
}

\author{
PhD in Pedagogy, Doctor of Philosophy, Associate Professor, Tetiana Kolodko \\ Ukraine, Kyiv, Department of Teaching Methodology of Ukrainian and Foreign Languages and \\ Literatures, Institute of Philology, Taras Shevchenko National University of Kyiv
}

DOI: https://doi.org/10.31435/rssglobal_sr/30092019/6681

\section{ARTICLE INFO}

Received 10 July 2019

Accepted 24 September 2019

Published 30 September 2019

\section{KEYWORDS}

teachers' professional development, 21st century skills, approaches, effective professional activities.

\begin{abstract}
The study was aimed to determine the importance of pursuing professional development of foreign language teachers. Three approaches to professional development such as theory-to-practice, coaching/mentoring and reflection are identified. The scientists' outlooks on the given issue are analyzed. Some recommendations for using mobile technologies in professional development are highlighted. Characteristics of effective professional development are substantiated in the study. Teachers' effective professional development activities are outlined.
\end{abstract}

Citation: Tetiana Kolodko. (2019) Pursuing Future Foreign Language Teachers' Professional Development. Science Review. 7(24). doi: 10.31435/rsglobal_sr/30092019/6681

Copyright: (C) 2019 Tetiana Kolodko. This is an open-access article distributed under the terms of the Creative Commons Attribution License (CC BY). The use, distribution or reproduction in other forums is permitted, provided the original author(s) or licensor are credited and that the original publication in this journal is cited, in accordance with accepted academic practice. No use, distribution or reproduction is permitted which does not comply with these terms.

Introduction. Not everyone sees the growth of English as a desirable phenomenon. But since English is now used more often as a lingua franca than as a native language - and since the majority of competent English speakers are not native speakers, but second-language users - the inner circle has lost much of its linguistic power, real or imagined. English language teachers lead their students down the road of pattern practice, only to find themselves confronted by a great gorge at the end. On the other side lies real communication, but the group is stranded on the other side of drills because the teacher sees no strong bridge across. Although there can be no doubt that the spread of English has some impact on other languages, creating a causal link between this.

While $21^{\text {st }}$ century skills are crucial everywhere, this notion seems to have found a deep resonance in Ukraine, where it features frequently in discussions of how to complement existing highly effective systems, which often produce superior performance on standardized examinations, with an emphasis on independence, creativity and innovation.

The $21^{\text {st }}$ century requires a new set of skills to keep up with our fast-paced, technology-driven world. Our students are growing up in a time of globalization in which our world is growing increasingly interconnected every day. Trilling B. and Fadel C. describe the shift foreign language teachers perceive in the following way: "This monumental shift from Industrial Age production to that of the Knowledge Age economy - information-driven, globally networked - is as world-changing and life-altering as the shift from the Agrarian to the Industrial Age hundred and fifty years ago" $[15,3]$. This shift requires from the learners to prepare themselves to be more connected with people and products from around the world and skilled at searching and processing new information independently. Learners growing up in the "Knowledge Age" will not be successful unless they learn how to process all the information that they will be inundated with throughout their lives. McCain T. and Jukes I. noted, "...In the past, when information had a much longer shelf life, learning was something that was done once in your youth. Then you were done with learning for life. In the good old days, what you learned in your youth prepared you for your single career. Today, learning has become a lifelong process. Given the rapidly changing nature of our world, people of all ages must 
constantly learn and relearn what they need to know. What they learned yesterday may no longer be valid in tomorrow's world. Tomorrow, they will have to learn again because today's information will already be out of date" [11, 89].

Research results. Teachers' training is a lifelong process. Teaching is lifelong learning. While investigating, we came to a thought that one of the joys of teaching is the opportunity to explore new ideas and new ways of teaching as well as we try to meet the needs of an ever-changing group of learners. If you never taught learners, then you will be learning a great deal during your first years about how to plan, manage, teach, and assess learners. Some is learned from experience. Some you may learn by talking with or observing more experienced colleagues. A language teacher may also continue to grow as a teacher of learners by participating in professional development activities sponsored by school or by a professional association, some of it face-to-face and some of it through online sources. If you are an experienced teacher, you may find that working with colleagues on curriculum or lessons or participating in a conference will enable you to share your experiences, develop a larger network of colleagues, and provide some new ideas or activities for your classroom $[4 ; 6]$.

The field of teaching learners English is constantly changing and growing, and the teacher wants to find appropriate ways to keep current. Being an effective English language teacher requires "the knowledge, skills, and sensitiveness of a teacher of learners" and "of a teacher of language", and the ability to balance these effectively in teaching $[3,269]$.

When thinking about some possible activities that help to develop as a teacher, they are likely could be grouped under one of the following three approaches to professional development, as identified by an English Professor Megan Wallace: a) theory-to-practice approach; b) coaching or mentoring approach; and c) reflective approach [16].

Let's dwell on each of them.

A Theory-to-Practice Approach (or teaching as science) is one in which teachers learn from experts by reading about their theories or listening to them speak at major conferences or in online webinars or podcasts, and then apply what they have learned in their teaching. And though current approaches to professional development (as well as teaching) are more focused on experience, and less on the transmission of ideas, one still can learn a lot from this approach by taking graduate classes, participating in workshops or seminars, or engaging in online discussion groups where experts and colleagues engage in discussion.

One way of organizing the information is to develop a set of questions to answer, such as:

1) What is one thing about the class that pleased me? Why?

2) What is one thing that did not go well? Why?

3) What might I do differently next time to address the problem?

A teacher might also want to make a list of aspects of teaching and learning to consider, as:

- Planning the lesson;

- Beginning the lesson;

- Giving directions;

- Managing the class;

- Encouraging participation by all learners;

- Providing feedback;

- Helping learners to develop listening, speaking, reading, or writing skills;

- Introducing and practicing vocabulary;

- Reducing teacher talk and increasing student talk;

- Other goals you have [7].

A Coaching or Mentoring Approach (or teaching as craft) is one in which less experienced teachers (or those with less experience in a particular skill or activity, such as using technology resources) learn from those with more experience and then apply that to their own teaching. Sometimes this involves collaborative coaching or even team coaching. Technology has made it possible to engage in many more professional development activities and to network with other teachers around the world.

Coaching and mentoring are particularly effective because they provide ongoing professional development that is teacher-directed, collaborative, and focused on immediate concerns and contexts. For example, you may find that you have much more experience and knowledge about how to integrate technology into your teaching than many of the other content teachers; offer to share that expertise with other teachers, perhaps through informal mentoring or longer-term coaching as they try to implement some of your suggestions [2]. 
A Reflective Approach (or teaching as critical thinking) is one in which teachers critically analyze or research, reflect upon, and adapt their own practice. Reflection helps the teachers to learn from their experiences, to become more conscious of what they do and why they are doing it, and analyze the results through systematic collection and analysis of information.

Prof. Donald Schön distinguished three main types of reflective practice:

reflection-in-action (thinking about what we are doing while we are doing it, in the classroom);

reflection-on-action (thinking about the class after it is over);

reflection-for-action (using what we have learnt from our reflections to plan for future classes) [14].

Of course, the last one, is the ultimate goal of reflection - to help the teacher plan for and implement more effective teaching and learning into practice.

More recent research has confirmed that teaching is also cognitively demanding; a teacher makes hundreds of nontrivial decisions daily, from designing lessons, to responding to students' questions, etc. So, teaching is a thinking person's job; it is not simply a matter of following a script or carrying out other people's instructuional designs, it's a keep up-to-date permanent process of change and growth. By working collaboratively, teachers can create communities that positively change the culture of their entire grade level, department, school etc.

Being an effective teacher requires the implementation of creative and innovative teaching strategies in order to meet students' needs. Here is a range of effective teaching strategies to inspire a classroom practice: a) visualization (using of interactive whiteboard to display photos, audio clips and videos, as well as encouraging students to get out of their seats with classroom experiments); b) cooperative learning (develop students' self-confidence, critical thinking and enhance their communication through solving puzzles, conducting scientific experiments and acting out a short drama sketches); c) inquiry-based instructions pose thought-provoking questions which inspire students to think for themselves and become more independent learners; d) differentiation in teaching by allocating task based activities; e) incorporating technology into your teaching; f) professional development programs is a great way to enhance teaching and learning in the classroom.

Being a professional teacher is a challenge because every student is unique, however, by using a combination of teaching strategies and tactics one can address students' varying learning styles and academic capabilities as well as make the classroom a dynamic and motivational environment for students in the educational framework [8].

In order to enhance professional and personal growth, teachers sometimes need to step outside the world of the classroom where the concentration is on knowledge and skills alone. It can be eyeopening to find out how important the teacher's approval is to students, how susceptible we are to teacher criticism, or realise how important it is for the teacher to set clear goals and guide students in other ways. As Luke Prodromou points out, "learning a foreign language has the advantage of offering personal and professional development at the same time for the same price" [12, 58].

Most teachers would agree that addressing $21^{\text {st }}$ century skills for learners is a must in education. Today to survive in this digital era critical thinking, problem solving ICT application, teamwork and innovation are the skills we need. To keep at par with the need of the age, educators curriculum should give importance to projects, individualized instructions, collaborative learning, Web Based learning and Lifelong learning. To develop the critical thinking skills of learners project based teaching is followed. Importance is given to enquiry-based learning. Asking questions, defining a problem, analyzing, peer learning, cooperative learning are promoted through the curriculum and teachers. Most of the lessons must have quizzes, projects and assignment to built teamwork among the students that also help the teachers to develop themselves.

The $21^{\text {st }}$ century skills that English Teachers should develop in learners are: IT skills; problem solving; critical thinking; creativity; identifying own self; communicating skills; listening skills; living in peace; co-operation. These skills can be developed through activity based learning where students get involved themselves willingly. Using technology in teaching and promoting high standards of student involvement in the lesson and creating opportunities for the learners to widen their horizon in the area of topics that they learn is one step. Creating experiment-based learning is another way of awakening their thinking power [1].

When planning the lessons, the teacher can make use of 3Hs, Head (Cognitive), Hand (Psycho-motor) and Heart (Affective/Feelings) and the specific objectives of the lesson can be divided under 3 sections where the student gets all the necessary abilities at the end of the lesson to become a knowledgeable, capable and worthy citizen for the country [18]. 
The key factor in the success of making productive-skill tasks is, in our opinion, the way teachers organize them and how they respond to the student's work using video or audio recording equipment. With access to video or audio recording equipment, teachers can also record their own classes, then analyze and reflect upon how they used the time, how their lesson progressed, whether the teacher interacted with all the students, or how much time he/she spent talking and how much time the teacher had the learners engaged in talking or writing. Making a number of recordings over the span of a term or a school year and analyzing and reflecting on them will help the teacher to see how much he/she has grown as a teacher during the year.

Before the listening activity (Warm-Up Stage), teachers prepare students by activating schemata, connecting the activity to their background knowledge, getting them to predict what they will be listening to, and introducing useful words and concepts, for instance: activate prior knowledge by showing pictures or realia (menu, movie schedule); prepare students for listening by contextualizing to make it more accessible and realistic; involve students in the specific topic by brainstorming (word map, listing); review known vocabulary; pre-teach unknown vocabulary.

What techniques can teachers use to make the vocabulary items comprehensible? The teachers can advise students to: use realia, pictures, flashcards, facial expressions; mime/act out the item; draw on the board; define; translate; give examples of the item; personalize; give synonyms or antonyms; use item in a sentence; help students examine morphemes to figure out the meaning and use of the item (e.g., review can be broken into 'view' = to see and 're' = again); tell what an item is not (e.g., a moose is not a person).

While students are listening (Presentation Stage), teachers must be sure that students are actively listening by using visuals (pictures, facial expressions, body movement, asking questions and eliciting answers, having them respond to the listening by doing, choosing, etc.).

Techniques for making input comprehensible: using visual cues, like pictures and flashcards; using gestures and body movement; using realia, graphic organizers (mind maps, timelines), or item in a sentence; using shorter and simpler sentences and phrases; giving a definition, synonym or antonym or an example; explaining the word or expression; demonstration; following directions; doing multiple choice tests, true or false tests; detecting mistakes in sentences; connecting students to the background knowledge.

Activities after listening (Practice and Application Stages) include the same types of activities mentioned above. These activities will reinforce students' understanding of the text and new vocabulary and grammar by getting them to apply the new language through controlled, guided, and independent activities.

As English in the $21^{\text {st }}$ century includes computer-mediated communication, it is important for teachers' development to learn how to communicate using new technology, such as Web 2.0 or usergenerated content, social media or social networking tools, and online Internet searching. According to a survey conducted by World Wide Web Technology Surveys (W3Techs) in September 2012, 55.1 percent of Web sites are in English. The next highest is German, with only 6.4 percent: English $55.1 \%$, German $-6.4 \%$, Russian $-5.1 \%$, Japanese $-4,9 \%$, Chinese $-4.7 \%$, Spanish $-4.7 \%$, French $4.3 \%$, Portuguese $-2.2 \%$, Italian $-2.0 \%$, Polish $-1.5 \%$, Turkish $-1.2 \%$, Dutch/Flemish $-1.1 \%$, Arabia - $1.1 \%$, Others - Under 1\% [17].

The most popular sites using English, according to W3Techs are: Google, Facebook, YouTube, Yahoo, Wikipedia, Live, Twitter, Amazon LinkedIn, and Google.co.in. This also means that it is important for teachers to help students improve their information and digital literacy, which entails using Internet search engines and basic skills for navigating Web sites effectively. Therefore, teachers should incorporate the up-to-date technology tools students' needs for communication in English without forgetting that these tools constantly change.

Another key factor in the success of making productive-skill tasks is the way teachers organize them and respond to the student's work using mobile phones with downloaded educational ones. Educational apps are making thing easier for students to understand. Moreover, books are often found to be tiring and boring for learners while replacing them with colorful pages, meaningful information and moving animations can make learning fun to the core.

Benefits of using mobile applications in teaching are as follows: 1) Enhanced interaction. Experts say that apps in education make learners more interactive and activate better engagement between parents and children. 2) New learning techniques. Technology in the guise of is helping those looking for some newness in the universe of learning. In addition to the feel of novelty, apps add an element of fun and involvement to the learning process. The games, puzzles or other challenging tasks, app learning stimulates the brain cells to actively metabolize the input releasing a new perspective. 3) Parent-teacher communication. The ideal concept of frequent parent-teacher interactions finds its 
space anytime and anywhere through the phone about the child's growth at school. 4) Online resources. The wealth of the online platform implicates its popularity among knowledge seekers. The reach of this platform makes it a favorite to those who can't afford full time courses in high schools or colleges. Mobile apps help them access a compendium of eBooks, pdfs and other online materials and the freedom to access it beyond the boundaries of time and space. 5) Entertainment. Due to studies [5; 9], mobile apps promote entertainment. Learning is no more a passive activity; it's active with applications. Lessons transforming to games can change the face of education. Besides learners will enable a kind of interest in learning and no more boring home works and tough class lectures. 6) Availability 24/7. Mobile applications unlike school are available round the clock. No need to be worried about schedules. Anywhere can be a classroom. App learning is not time-bound learning, it's relaxed learning. Moreover, most of the apps promote child-friendly control. 7) Leisure hour's utilization. No responsible parents want their kids to get addicted to the phone. Too much Internet usage isn't a wise option for killing time. This is where mobile apps prove their worth. Mobile app learning is among the wisest choices of utilizing a free time actively. 8) Routine tasks. It's a relief to get all the tasks done with a few taps. Be it tasks like fee payment, other transactions that require us to stand in a queue for hours or the laborious job of marking attendance that drives teachers crazy with amount of paperwork having each day. All this drudgery has been put to an end simply by having apps in place. 9) Filling in the gaps. The advancement that schools have seen eliminated many glitches that prevailed in the education system. A major one is the lack of interaction between the teachers and the teachers. Phone apps and websites have been created to help reduce the gap not between the students and the educators but also among parents and the teachers. 10) Systematic learning activated. Mobile apps help in systematic learning. Apps are arranged in such a systematic way that it becomes possible for students to go with the flow without even realizing. 11) Portability. There are no restrictions for mobile phones. They can be constant companions of teachers, parents and students. Thereby, apps are available to learners all the time. Learning won't be confined to the classrooms only. 12) Instant updates. There are some phone apps, which stay updated about different learning events, timetables and other important information. They provide opportunities to interact with students throughout the life cycle, post-graduate students, colleagues, and alumni. 13) Track your students' progress. With some apps, you can track your students' progress, which is one of the important things that every teacher wants to know. Along with the progress, you can visualize how each app helps your students improve their skills such as writing, speaking, listening. 14) Staying connected. Educational apps are the best way for learners to stay connected with their teachers. Though the way of learning through apps is entirely different from the traditional learning method, it adds to the entire process [10].

The most commonly used model for future foreign language teacher training in new technologies is Content and Language Integrated Learning (CLIL). It involves a set of so-called $21^{\text {st }}$ century skills, which amongst other things include creativity and innovation, critical thinking and problem solving, collaboration and teamwork, autonomy and flexibility, and lifelong learning, all bundled together with digital literacies. Many educators emphasize the importance of $21^{\text {st }}$ century skills for individuals' personal agency, helping them to lead fulfilling personal and social lives, and enabling them to participate as engaged teachers in national and international conversations [2;8]. For educators, it is important to develop a critical mobile literacy because it offers a lens through which to focus on finding a balance among competing interests and help students open up spaces for growth amid the multiple discourses. New literacies and new skills don't only improve the chance of selfrealization through economic opportunity but increase the richness of personal and social lives, and make it easier to acquire a 'voice' in local, national and international conversations [9]. So, this model helps teachers to be contemporary.

With the incredible range of resources available through the Internet, it is possible to read current articles or explore an area of interest teachers were not able to do previously. Teachers may be able to do this with colleagues in other countries, sharing ideas with them as well as learning from them.

Teachers might want to become part of an online discussion group focused on an area in which they are particularly interested (for example, integrating technology into language teaching or language assessment). Usually there is a moderator who initiates the discussion or even invites a recognized expert to answer questions and suggest readings for further learning. Or teachers can attend workshops or register for podcasts or other online professional development opportunities often available without cost. Short-term online professional development courses or certificate programs offered by universities, the TESOL International Association, the IATEFL International Association or the U.S. Embassy. Studies have shown that these online learning environments can be very 
effective in building professional connections and finding solutions to teaching challenges through the social interaction that occurs in the discussion forums in online courses [13].

One of the best ways to keep up to date as an English teacher is to participate in professional associations or organizations. Both mentioned above organizations, TESOL and IATEFL are focused directly on English language teaching. Besides an annual conference, they also provide publications, extensive online teaching resources, and other professional development opportunities such as symposia, workshops, podcasts, or webinars.

Conclusions. As technological level increase, so do the teachers' development in the $21^{\text {st }}$ century along with the associated demands on teachers. With appropriate technology at their disposal, effective teachers can and should become examples for their students. As educators teachers need experience in the productive aspects of multiple mobile literacy and. As innovators teachers must add to their repertoire the information language skills to identify, evaluate and catalogue relevant content, complemented by the network literacy skills to leverage online connections to help discover as well as scatter this content. It will also allow them to mentor their students in developing the opportunity to share their knowledge and experience.

The study conducted does not solve all the above mentioned problems. The perspective of the further research is to outline the students' stimuli for their self-education and teachers' creativity in adaptation to changes in innovative environment.

\section{REFERENCES}

1. Bonk, C.J. (2009). The world is open: How Web technology is revolutionizing education. San Francisco: Jossey-Bass.

2. Borko, H. (2004). Professional Development and Teacher Learning: Mapping the terrain. Educational Researcher. 33(8). - P. 3-15.

3. Brewster, J., Ellis, Girald, D. (2010). The primary English teacher's guide. Essex, UK: Pearson.

4. Crandall, J.A. (2001). Keeping up to date as an ESL or EEL professional. In M. Celce-Murcia (Ed.), Teaching English as a second or foreign language, 3rd ed. (pp. 535-552). Boston, MA: Heinle \& Heinle.

5. Dikkers, S. (2011). Dewey Buys a Smartphone. Mobile Media Learning: Amazing Uses of Mobile Devices for Learning. Pittsburgh, PA: ETC Press.

6. Egbert, J. (Ed.). (2003). Becoming contributing professionals. Alexandria, VA: TESOL.

7. Katherine J. Klein, Joann S. Sorra (1996). The Academy of management Review. Vol. 21, № 4 (Oct., 1996). - P. 1055-1080.

8. Kolodko, T. (2018). On Becoming a Language Teacher: Insights From Studies // Norwegian Journal of Development of the International Science. - № 20, Vol. 2, Part 2. - Oslo, Norway. - P. 55-58.

9. Kolodko T. (2018). Continuing Professional Development of English Language Teachers: Focus on English Teaching Framework // Danish Scientific Journal. - Denmark. - 2018, № 19, Vol. 2. - P. 57-60.

10. Kolodko, T. (2019). Foreign Language Teachers' Preparing for a Mobile Educational Future // Scientific International Journal «Science and Education a New Dimension». Pedagogy and Psychology», VII (80), Issue: 198. - Budapest: Society for Cultural and Scientific Progress in Central and Eastern Europe, 2019 Maj. - P. 20-23.

11. McCain, T., Jukes, I. (2001). Windows on the future: Education in the age of technology. Thousand Oaks, CA: Corwin Press.

12. Prodromou, L. (2002). Crossing frontiers. English Teaching Professional. - № 23. - P. 58.

13. Shin, J.K., Bickel, B. (2012). Building an online community of inquiry with participant-moderated discussions. In L. England (Ed.), Online language teacher education: TESOL perspectives. New York, NY: Routledge (Taylor Francis).

14. Schön, D.A. (1983). The reflective practitioner. How professionals think in action. New York, NY: Basic Books.

15. Trilling B., Fadel, C. (2009). $21^{\text {st }}$ century skills: Learning for life in our times. San Francisco, CA: Jossey-Bass.

16. Wallace, M.J. (1996). Training foreign language teachers. Cambridge, UK: Cambridge University Press.

17. http://w3techs.com

18. http://languageteachingtips.wordpress.com/2012/06/20/keeping-a-reflective-teaching-diary/ 